\title{
An unusually coloured individual of the common spadefoot toad Pelobates fuscus (Laurenti, 1768)
}

\author{
Piotr Paweł KAZIMIRSKI
}

Naturalist's Club 1 Maja 22, 66-200 Świebodzin, Poland; kazimirski.piotr@gmail.com

\begin{abstract}
The background colouration of the spadefoot toad Pelobates fuscus, an anuran species found in Europe is typically light grey/yellow grey/light olive-green. However, an atypical specimen, whose background was brightly coloured yellowish green (light green/lime/yellow coloured), with darker small spots distributed through dorsal parts and four main spots slightly shaped was observed in Poland (Great Poland, Mościejewo village), near to two ponds. The ecological effects of green coloured individual can be adaptively important, through its similarity to the vegetation (predator avoidance).
\end{abstract}

Key words: amphibians, chromatophores, green, colour morphs

\section{INTRODUCTION}

Amphibians' colouration provides aposematic or cryptic skin patterns which protect them from visual predators and inform another conspecifics about the condition, sex and maturity of a given individual (Vitt \& Caldwel 2014). Every species in the amphibians group has certain and constant patterns of colouration which can also be a useful tool for individual recognition (Plăiaşu et al. 2005). Colouration in amphibians can vary over quite a wide range compared, for example, to birds or mammals. Amphibians can switch coloration between pale and dark depending on stress or life stage (Bagnara \& Hadley 1973).

Depending on individual specific aspects and genetic, a number of colour aberrations can be distinguished as: melanism, axantism, albinism, leucism, erythrism, flavism, hypomelanism (Henle et al. 2017). These most common aberrations are usually an effect of gene mutations which affect chromatophores and/or pigment distribution, production or development (Duellman \& Trueb 1994). Such deviations like albinism can also affect eggs (e. g. Kaczmarski \& Kaczmarek 2018). Chromatophores determine particular colours in amphibians and are located in the dermis.

The spadefoot toad is a peculiarly nocturnal European anuran species (Speybroeck et al. 2016) and their typical background colourations are: light grey, yellow grey or light olive-green with four dark brown main spots with shape variations (Fig. 1.) (Speybroeck et al. 2016).

\section{OBSERVATION}

In the village of Mościejewo $\left(52^{\circ} 35^{\prime} 05.7^{\prime \prime} \mathrm{N}, 16^{\circ} 08^{\prime} 50.3^{\prime \prime E}\right.$, Greater Poland province, Poland), on 23 May 2020, at night (new moon), I recorded the common spadefoot toad Pelobates fuscus (51 mm, male) whose whole background was yellowgreen, with darker small spots present from the neck to the cloaca and four main spots slightly shaped (Fig. 1.). It was the only spadefoot toad's individual I noticed that night. This individual was spotted in the rainfall along the path connecting two ponds: one small, temporary and the other larger, intendent for fish. The place where I found the described specimen were surrounded by road, trees and grass. 

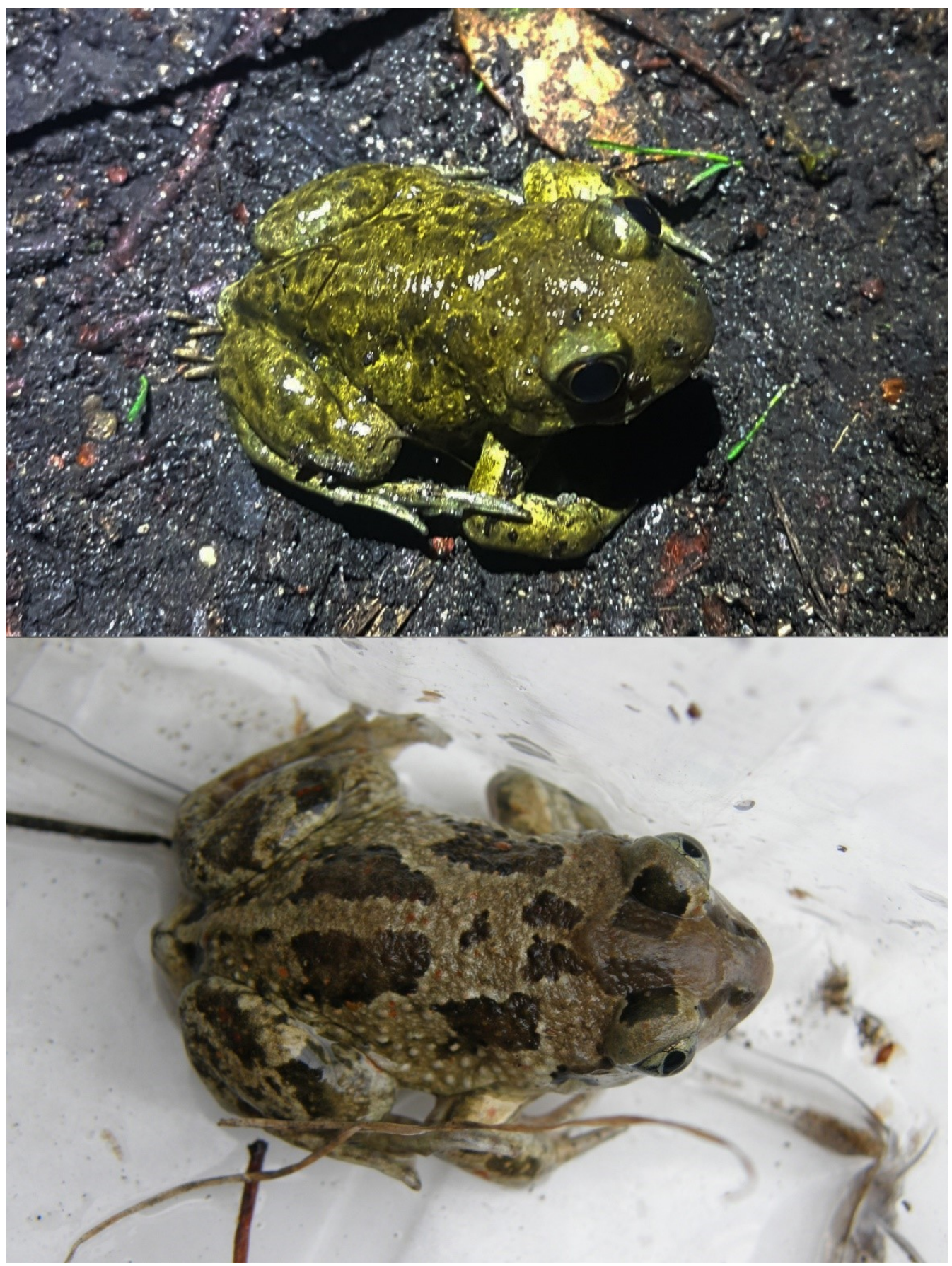

Fig. 1. Unusually coloured spadefoot toad individual (at the top, photo by P. Kazimirski) and a typically coloured individual (at the bottom, photo by M. Kaczmarski). 
There are some reports from Poland about rare colour variants among amphibians (Kolenda et al. 2017, Kazimirski \& Sommer 2018). The authors described, for instance, the strongly red spadefoot toad morph. However, individuals with a different amount of red in this species may appear in populations quite often, therefore the red colouration should be treated as a rare phenotype and not as an abnormal colouration. In the case of a group of juveniles rearing in mesocosm catched as a tadpoles stage from farmland pond in Sady near Poznań at 2020 it was found $17 \%$ red coloured individuals, $\mathrm{n}=40$ (Kaczmarski, unpubl. data). Therefore, the speculations of Kolenda et al. (2017) concerning the genesis of the red colouring P. fuscus (result of the high concentration of iron in water and ground) seem to be exaggerated.

It seems that I found an individual which could be described as a rare morph in Juszczyk (1987). The rarest conspecifics are these which have poorly shaped main spots or no spots, wherein the latter's dorsal colour is: citrine drab, olive buff or dark-olive buff, covered with small light spots (Juszczyk 1987). The four slightly shaped main spots that occurred on my specimen do not seem to match this pattern. Occurrence of the four main spots seems to prove that melanophores are prevalent but in weaker form, whilst yellow xantophores are more common than in typicall coloured individual. The above can explain highly bright green colour. The reason of its colouration can be attached to pond features such as turbid water, which causes paler tadpole's colour (Thibaudeau \& Altig 2012) or background coloration (Rodriguez et al. 2021) which seems to be more appropriate explanation.

Bright colours may attract females as found by Vásquez \& Pfennig (2007) in Couch's spadefoot toad Scaphiopus couchii. They found also that both - colour patterning and intensity are condition and size related (positive) in males. The ecological effects of completely green coloured spadefoot toads can have adaptive properties, through this colouration background is similar to the surrounding vegetation, unlike leucistic, xantic or albinistic individuals, which are more apparent to the potential predator. Hence, in specific environments with a high amount of vegetation, this feature can be quite positive.

\section{ACKNOWLEDGEMENTS}

I thank Mikołaj Kaczmarski for sharing unpublished data and his help with writing the natural history note. Thanks to the anonymous reviewers for valuable comments.

\section{REFERENCES}

Bagnara J. T. \& Hadley M. E. 1973. Chromatophores and colour change. The Comparative Physiology of Animal Pigmentation. Prentice-Hall, Englewood Cliffs, NJ.

Duellman W. E. \& TRUeB L. 1994. Integumentary, sensory, and visceral systems. In: Biology of amphibians. JHU press: $374-378$.

Henle K., Dubois A. \& Vershinin V. 2017. A review of anomalies in natural populations of amphibians and their potential causes. In: HENLE K. \& DUBOIS A. (eds). Studies on anomalies in natural populations of amphibians. Mertensiella 25: 115-124.

JusZCZYK W. 1987. Gady i płazy. Second Edition, Warsaw, Wiedza Powszechna.

KACZMARSKI M. \& KACZMAREK J. M. 2018. Albino clutch of moor frog Rana arvalis-a rare observation from Poland. Fragmenta Faunistica 61 (1): 61-64.

KAZIMIRSKI P. \& SOMMER A. 2018. Rzadko spotykana forma barwna grzebiuszki ziemnej Pelobates fuscus (Laurenti, 1768). Wszechświat 119: 04-06.

Kolenda K., NAJBAR B., NAJBAR A., KACZMAREK P., KACZMARSKi M. \& SKAWiŃSKi T. 2017. Rare colour aberrations and anomalies of amphibians and reptiles recorded in Poland. Herpetology Notes 10: 103-109.

Plăiaşu R., Hartel T., Băncilă R. I., \& Cogălniceanu D. (2005). The use of digital images for the individual identification of amphibians. Studii şi Cercetări, 10, 137-140.

SPEYBRoECK J., BEUKEMA W., BOK B. \& VAN DER VOORT J. 2016. Field guide to the amphibians and reptiles of Britain and Europe. Bloomsbury publishing: 139-140. 
RodríGUEZ-RodríGUEZ E. J., BELTRÁN J. F. \& MÁRQUEZ R. 2021. Melanophore metachrosis response in amphibian tadpoles: effect of background colour, light and temperature. Amphibia-Reptilia 42 (1): 133-140. DOI: 10.1163/15685381-bja10032

ThiBaudeau G. \& Altig R. 2012. Coloration of anuran tadpoles (Amphibia): development, dynamics, function, and hypotheses. International Scholarly Research Notices, Zoology, 2012, 725203, 16 pp. DOI: 10.5402/2012/725203

VÁsQUEZ T. \& PFENNIG K. S. 2007. Looking on the bright side: females prefer coloration indicative of male size and condition in the sexually dichromatic spadefoot toad, Scaphiopus couchii. Behavioral Ecology and Sociobiology 62(1): 127-135. DOI: 10.1007/s00265-007-0446-7

ViTT L.K. \& CALDWELL J.P. 2014. Herpetology. An introductory biology of amphibians and reptiles. Academic Press, Elsevier. NewYork: 697 pp.

\section{STRESZCZENIE}

\section{[Niezwykle ubarwiony osobnik grzebiuszki ziemnej Pelobates fuscus (Laurenti, 1768)]}

Nietypowo ubarwiony samiec grzebiuszki ziemnej Pelobates fuscus, pospolitego europejskiego gatunku płaza bezogonowego, został zaobserwowany w Wielkopolsce (wieś Mościejewo). Typowo ubarwiony grzbiet grzebiuszki ziemnej jest na ogół jasnoszary, żółtoszary lub jasno oliwkowo-zielony, zaś spotkany okaz miał cały grzbiet wyjątkowo jaskrawo ubarwiony, w kolorze zółtojasnozielonym, z małymi plamami występującymi od karku do kloaki i czterema słabo zaznaczonymi, głównymi plamami koloru szarozielonego. Mimo, iż grzebiuszka ziemna jest gatunkiem pospolitym, zaobserwowane ubarwienie nie było dotąd opisywane w literaturze europejskiej. Zielone ubarwienie (poprzez upodobnienie do traw) może nieść za sobą pozytywne konsekwencje, takie jak np. zwiększenie przeżywalności w sprzyjającym ku temu terenie. 